\title{
LEGALITAS KONTRAK BISNIS DALAM PERSPEKTIF HUKUM NASIONAL DAN HUKUM HINDU
}

\author{
I Gusti Agung Wisudawan \\ Fakultas Hukum Universitas Mataram \\ Email korespondensi: agung.wisudawan@gmail.com
}

\begin{abstract}
ABSTRAK
Legalitas kontrak bisnis sering kali menjadi masalah seperti tidak dipenuhinya syarat sahnya kontrak seperti yang berkaitan dengan kesepakatan, kecakapan hukum para pihak, obyek hukum yang diperjanjikan dan kausa yang halal sebagaimana yang telah diatur di dalam Pasal 1320 KUH Perdata, ternyata dalam hukum Agama Hindu diatur juga tentang keabsahan atau legalitas kontrak/perjanjian bisnis yaitu dalam kitab Manava Dharmasastra (Manu Dharmasastra) atau Veda Smrti (Compedium Hukum Hindu) Hasil penelitian diharapkan dapat dimanfaatkan mengembangkan konsep-konsep hukum khususnya Hukum Bisnis dan Hukum Ekonomi Hindu sehingga dapat dimanfaatkan oleh para akademisi dan praktisi dalam mendalami hukum bisnis maupun hukum agama khususnya Hukum Agama Hindu. Adapun jenis penelitian yang digunakan dalam penelitian ini adalah Penelitian Normatif. Legalitas kontrak bisnis menurut hukum nasional terdapat di dalam Pasal 1320 KUH Perdata yaitu tentang syarat sahnya suatu perjanjian, sedangkan legalitas kontrak dalam Kitab Manusmerti atau Manawa Dharmasastra diatur di dalam Pasal 163, Pasal 164, Pasal 168.
\end{abstract}

Kata Kunci: Legalitas, Kontrak Bisnis, Hukum Nasional, Hukum Hindu

\begin{abstract}
In economic activity, contracts have a major role because they are related to the legality of legal acts committed by the parties. The legality of a business contract is often a problem such as not fulfilling the legal conditions of the contract, such as those relating to agreements, the legal prowess of the parties, the agreed legal objects and lawful causes as regulated in Article 1320 of the Civil Code, it turns out that in Hindu religious law it is also regulated. Regarding the validity or legality of business contracts / agreements, namely in the book Manava Dharmasastra (Manu Dharmasastra) or Veda Smrti (Compedium Hukum Hindu), so that in this scientific journal we will describe the legality of business contracts in the perspective of national law and Hindu law. The type of research used in this research is Normative Research with a statutory approach (Statute Approach), a conceptual approach (Coceptual Approach). This study also uses legal materials which consist of primary legal materials, namely legal materials in the form of the Civil Code and Manava Dharmasastra (Manu Dharmasastra) or Veda Smrti (Compedium of Hindu Law), secondary legal materials, namely literature related to the issues raised in this study and materials Tertiary Law consists of a legal dictionary and encyclopedia. Legal material collection techniques used in this research is a Documentation Study with Legal Material Analysis, namely Qualitative Descriptive Analysis.

Keywords: Legality, Business Contracts, National Law, Hindu Law
\end{abstract}




\section{PENDAHULUAN}

Perkembangan hukum kontrak di era globalisasi pada saat ini mengalami kemajuan yang sangat berarti, tidak ada suatu pun perbuatan hukum dalam bidang perekonomian yang tidak didahului dengan kontrak (sering disebut ada hitam di atas putih). Pentingnya kontrak bisnis harus diikuti dengan pemahaman yang komperhensif tentang aspek legalitas kontrak yang saat ini sering sekali dibaikan oleh pelaku ekonomi, selain itu pemahaman terhadap ketentuan umum dalam hukum kontrak menjadi sesuatu yang sangat penting sebab jika tidak dipahami maka akan menimbulkan kasus hukum atau perselisihan (dispute) seperti wanprestasi.

Aspek legalitas kontrak bisnis yang dilakukan baik secara offline maupun secara online menjadi sangat penting karena bukan hanya melibatkan para pihak yang berasal dari Indonesia saja, tetapi juga melibatkan pihak yang berasal dari negara lain. Oleh karena itu pemahaman aspek legalitas harus diketahui secara sistematis dan masif bukan hanya hukum perdata nasional tetapi juga hukum perdata internasional. Sebab ukuran legalitas kontrak di setiap negara berbeda walaupun maksudnya akan sama, hal ini terjadi karena setiap negara menganut sistem hukum yang berbeda (Family Recht) seperti Common Law System, Civil Law System, Religius Law System dan Socialis Law System.

Selanjutnya ada hal yang sangat menarik yang dapat dikaji maupun dianalisis yaitu ternyata dalam hukum Agama Hindu diatur juga tentang aspek legalitas kontrak/perjanjian bisnis yaitu Manava Dharmasastra (Manu Dharmasastra) atau Veda Smrti (Compedium Hukum Hindu) dan Arthaśāstra yang ditulis oleh Kautilya Vishnugupta, sebagai agama yang tertua di dunia Agama Hindu merupakan Sanatana Dharma yang artinya kebenaran yang abadi. Pemahaman terhadap ajaran agama hindu bukan hanya selalu berbicara tentang ritual keagamaan belaka tetapi lebih luas dari itu yaitu theologi hindu/filsafat hindu dan hukum hindu khususnya yang berkaitan dengan kegiatan ekonomi dan bisnis contohnya perjanjian atau kontrak. Oleh karena itu Penulis tertarik untuk membahas tentang tentang legalitas kontrak bisnis dalam perspektif hukum nasional dan hukum hindu. Berdasarkan latar belakang sebagaimana yang telah diuraikan di atas, maka permasalahan yang akan menjadi kajian dari penelitian ini adalah Legalitas Kontrak Bisnis Dalam Perspektif Hukum Nasional dan Hukum Hindu.

\section{METODE PENELITIAN}

Adapun jenis penelitian ini adalah penelitian Normatif yaitu penelitian yang mengkaji dan menganalisis tentang peraturan perundang-undangan maupun peraturan lain yang ada hubungannya dengan permasalahan di atas. Metode pendekatan yang digunakan dalam penelitian ini adalah Pendekatan Perundangundangan (Statute Approach), Pendekatan Konseptual (Conceptual Aprroach).

Adapun jenis dan sumber bahan hukum yang digunakan dalam penelitian ini adalah sebagai berikut :Bahan Hukum Primer yaitu bahan hukum yang berupa peraturan perundang-undangan yang berlaku serta ada kaitannya dengan permasalahan yang akan dibahas yaitu Kitab Undang-Undang Hukum Perdata dan Manava Dharmasastra (Manu Dharmasastra) atau Veda Smrti (Compedium Hukum Hindu). Bahan Hukum Sekunder yaitu bahan hukum yang menjelaskan 
bahan hukum primer, yakni berupa hasil penelitian, buku-buku teks, seminar, diskusi dan berita internet.Adapun teknik pengumpulan bahan hukum yang penulis gunakan dalam penelitian ini adalah studi dokumentasi,Bahan Hukum yang telah terkumpul dalam penelitian ini kemudian dianalisis dengan mengunakan metode Analisis Deskriptif Kualitatif.

\section{HASIL DAN PEMBAHASAN \\ Legalitas Kontrak Bisnis Dalam Perspektif Hukum Nasional dan Hukum Hindu}

Negara Indonesia adalah negara yang berdasarkan atas hukum sebagaimana yang diamanatan di dalam konstitusi aitu Undang-undang Dasar Negara Republik Indonesia Tahun 1945. Ha ini berarti bahwa segala aktivitas yang dilakukan di masyarakat harus berdasarkan hukum. Tentu dalam hal ini hukum harus menjadi panglimanya ditaati oleh masyarakat karena hukum sejatinya mengontrol kegiatan sosial kemasyarakatan (law as tool of social control). Adapun tujuan yang ingin dicapai oleh hukum adalah keadilan, kepastian, kemanfaatan dan keberlanjutan atau sustainable untuk kesejahteraan masyarakat. Kegiatan bisnis sebagai bentuk implementasi dari perbuatan hukum tidak bisa lepas dari kontrak atau perjanjian sebagai dasar hubungan hukum antara para pihak. Berikut ini Penulis akan menguraikan tentang definisi dari Kontrak Bisnis atau Perjanjian. Pengertian sederhana dari Kontrak bisnis yaitu perbuatan hukum yang didasari dengan kata sepakat antara subjek hukum yang satu dengan subjek hukum yang lain dalam bidang harta kekayaan dimana subjek hukum yang satu berhak atas suatu prestasi dan subjek hukum yang lain berkewajiban untuk memenuhi prestasi. Terdapat beberapa unsur dalam definisi ini yaitu :

1. Adanya perbuatan hukum

2. Kesepakatan

3. Subjek Hukum

4. Prestasi

5. Hak dan Kewajiban

Dalam hukum perdata nasional perjanjian atau kontrak diatur di dalam Pasal 1313 yang menyatakan bahwa: "Suatu perjanjian adalah suatu perbuatan dengan mana satu orang atau lebih mengikatkan dirinya terhadap satu orang lain atau lebih". Definisi dalam Pasal 1313 ini belum jelas karena tidak jelas karena setiap perbuatan merupakan perjanjian, tidak terlihat tentang kesepakatan para pihak padahal kesepakatan adalah hal yang terpenting dalam kontrak bisnis dan bersifat dualisme.

Adapun asas-asas dalam hukum perjanjian yaitu :

1. Asas Kebebasan Berkontrak

2. Asas Konsensualisme

3. Asas Pacta Sunt Servanda

4. Asas Itikad Yang Baik

5. Asas Kepribadian (Salim HS 2006:157)

Adapun uraian tentang asas-asas hukum perjanjian di atas adalah :

1. Asas Kebebasan Berkontrak

Asas ini diatur di dalam Pasal 1338 ayat (1) KUH Perdata yang berbunyi “ Semua perjanjian yang dibuat secara sah berlaku sebagai undang-undang bagi mereka yang membuatnya". Asas kebebasan berkontrak adalah suatu asas yang memberikan kebebasan bagi para pihak untuk membuat atau tidak membuat 
perjanjian, mengadakan perjanjian dengan siapapun, menentukan isi perjanjian, pelaksanaaan dan persyaratannya serta menentukan bentuknya perjanjian yaitu tertulis atau lisan. Khusus untuk perjanjian baku asas ini tidak bisa diterapkan sebab perjanjian baku merupakan perjanjian yang dibuat secara sepihak, sehingga salah satu pihak saja yang menentukan isi atau substansi perjanjian, sedangkan pihak lainnya tunduk kepada persyaratan yang telah dibuat oleh pihak yang sebelumnya, contohnya perjanjian kredit.

2. Asas konsensualisme

Asas ini diatur di dalam Pasal 1320 ayat (1) KUH Perdata . dalam pasal itu ditentukan bahwa salah satu syarat sahnya perjanjian yaitu adanya kesepakatan antara kedua belah pihak. Kesepakatan merupakan persesuaian kehendak dan pernyataan yang dibuat oleh kedua belah pihak.

3. Asas Pacta Sunt Servanda

Merupakan asas bahwa hakim atau pihak ketiga harus menghormati substansi kontrak yang dibuat oleh para pihak sebagaimana layaknya sebuah undangundang. Mereka tidak boleh melakukan intervensi terhadap substansi kontrak yang dibuat oleh para pihak. Asas ini juga disebut sebagai asas kepastian hukum yang berhubungan dengan akibat suatu perjanjian.

4. Asas Itikad Yang Baik

Asas ini diatu di dalam Pasal 1338 ayat (3) KUH Perdata yang berbunyi" Perjanjian harus dilaksanakan dengan itikad yang baik". Artinya bahwa pihak kreditur dan debitur harus melaksanakan substansi kontrak berdasarkan kepercayaan dan keyakinan yang teguh dan kemauan yang baik dari para pihak.

5. Asas Kepribadian

Merupakan asas yang menentukan bahwa seseorang yang akan melakukan dan atau membuat kontrak hanya untuk kepentingan perseorangan saja. Hal ini diatur di dalam Pasal 1315 KUH Perdata yang berbunyi " Pada umumnya seseorang tidak dapat mengadakan perikatan atau perjanjian selain untuk dirinya sendiri". Inti dari ketentuan ini adalah seseorang yang mengadakan perjanjian hanya untuk kepentingan dirinya sendiri.

Kelima asas di atas wajib diikuti dan dilaksanakan di dalam pembuatan perjanjian baik perjanjian yang bersifat Nominaat (Perjanjian yang terdapat di dalam KUH Perdata seperti Jual Beli, Sewa Menyewa, Penitipan Barang, Pinjam Meminjam, Pinjam Pakai, Pemberian Kuasa dan Perdamaian) maupun perjanjian yang bersifat Innominaat (Perjanjian yang terdapat di luar KUH Perdata yaitu Perjanjian Kredit, Leasing, Pembiayaan proyek, Pembiayaan Konsumen dll).

Menurut Niewenhuis, menyatakan ada tiga asas hukum kontrak dan pengecualiannya yaitu :

a. Asas Kebebasan Berkontrak (menurut bentuk dan isi) dengan pengecualian kontrak-kontrak formal dan rill (bentuk) dan syarat kausa yang diperbolehkan (isi).

b. Asas Daya Pengikat Kontrak (perkecualian: daya membatas iktikad baik dan overmacht) dan

c. Asas bahwa perjanjian hanya menciptakan perikatan di antara para pihak yang berkontrak (perkecualian kepentingan pihak ketiga). (Agus Yudha Hernoko 2010:105) 
Adapun momentum terjadinya suatu kontrak apabila telah ada kesepakat antara para pihak yang membuat suatu perjanjian, tentang kesepakatan ini pun juga telah diatur dalam Kitab Manawa Dharmasastra yang intinya dalam setiap perbuatan hukum baik dalam hal kotrak atau perjanjian dan hukum keluarga harus didahului dengan adanya kesepakatan jika tidak memenuhi kata sepakat maka Manu menganggap perjanjian itu tidak sah. Dalam hukum nasional terdapat beberapa teori tentang kesepakatan yaitu :

1. Teori Perrnyataan (Uitingstheorie)

Menurut teori pernyataan, kesepakatan (toesteming) terjadi pada saat pihak yang menerima penawaran menyatakan bahwa ia menerima penawaran itu. Jadi, dilihat dari pihak yang menerima, yaitu pada saat baru menjatuhkan ballpoint untuk menyatakan menerima, kesepakatan sudah terjadi. Kelemahan teori ini adalah sangat teoretis karena dianggap terjadinya kesepakatan secara otomatis.

2. Teori Pengiriman (Verzendtheorie)

Menurut teori pengiriman, kesepakatan terjadi apabila pihak yang menerima penawaran mengirimkan telegram. Kritik terhadap teori ini, bagaimana hal itu bisa diketahui. Bisa saja, walau sudah dikirim tetapi tidak diketahui oleh pihak yang menawarkan. Teori ini juga sangat teoretis, dianggap terjadinya kesepakatan secara otomatis.

3. Teori Pengetahuan (Vernmingstheorie)

Teori pengetahuan berpendapat bahwa kesepakatan terjadi apabila pihak yang menawarkan mengetahui adanya acceptatie (penerimaan), tetapi penerimaan itu belum diterimanya (tidak diketahui secara langsung). Kritik terhadap teori ini, bagaimana ia mengetahuinya isi penerimaan itu apabila ia belum menerimanya.

4. Teori Penerimaan (Ontvangstheorie)

Menurut teori penerimaan bahwa toesremiug terjadi pada saat pihak yang rrrenawarkan menerima langsung jawaban dari pihak lawan. (Salim HS 2010:166)

Selanjutnya dalam hukum nasional Indonesia yaitu Kitab Undang-Undang Hukum Perdata Perjanjian yang dibuat oleh para pihak tentunya harus memenuhi persyaratan tentang sahnya atau legalnya suatu kontrak yaitu yang diatur di dalam Pasal 1320 KUH Perdata, adapun syarat sahnya perjanjian adalah : (Salim HS, 2006:162-165)

a. Kesepakatan kedua belah pihak.

Kesepakatan adalah persesuaian pernyataan kehendak antara satu orang atau lebih dengan pihak lainnya. Yang sesuai itu adalah pernyataannya, karena kehendak itu tidak dapat dilihat dan diketahui oleh orang lain.

a. Kecakapan bertindak

Kecakapan bertindak adalah kecakapan atau kemampuan untuk melakukan perbuatan hukum. Orang-orang yang akan mengadakan perjanjian haruslah orang-orang yang cakap dan mempunyai wewenang untuk melakukan perbuatan hukum, sebagaimana ditentukan oleh undang-undang yaitu telah dewasa dan tidak dibawah pengampuan (curatele). 
b. Adanya objek perjanjian.

Yang dimaksud dengan objek perjanjian disini adalah prestasi (pokok perjanjian). Prestasi adalah apa yang telah menjadi kewajiban debitur dan apa yang menjadi hak kreditur. Perstasi terdiri atas memberikan sesuatu, berbuat sesuatu dan tidak berbuat sesuatu.

c. Adanya kausa yang halal

Artinya barang yang dijadikan sebagai objek perjanjian tidak bertentangan dengan undang-undang, ketertiban umum, dan ketertiban umum.

Syarat yang pertama dan kedua disebut sebagai syarat subjektif, karena menyangkut pihak-pihak yang mengadakan perjanjian. Sedangkan syarat ketiga dan keempat disebut syarat objektif karena menyangkut objek perjanjian. Jika syarat pertama dan kedua tidak terpenuhi maka perjanjian itu dapat dibatalkan melalui putusan pengadilan, sedangkan jika syarat ketiga dan keempat tidak terpenuhi maka perjanjian batal demi hukum, yang artinya bahwa seolah-olah tidak ada perjanjian sebelumnya.

Berdasarkan hal tersebut di atas jelaslah bahwa menurut hukum nasional sebagaimana yang dimaksud dalam KUH Perdata legalitas suatu kontrak bisnis harus memenuhi unsur sebagaimana yang dimaksud di dalam Pasal 1320 KUH Perdata. Jika tidak memenuhi unsur di dalam pasal tersebut maka legalitas kontrak itu tidak terpenuhi atau dengan kata lain cacat hukum. Sebagai perbandingan di negara yang menganut Sistem Hukum Common Law System seperti Amerika dan Inggris syarat sahnya/ legalitas suatu perjanjian/kontrak yaitu :

1. Adanya offer (penawaran) dan acceptance (penerimaan)

2. Meeting Of Minds (persesuaian kehendak)

3. Konsiderasi (prestasi)

4. Competent Legal Parties (kewenangan hukum para pihak)

5. Legal Subjek Matter (pokok persoalan yang sah)

Sebenarnya jika dikaji secara seksama ada kemiripan antara syarat sahnya perjanjian di Indonesia yang menganut Sistem Hukum Civil Law System dengan syarat sahnya perjanjian di Amerika dan Inggris yang menganut Sistem Hukum Common Law System, istilahnya yang berbeda tetapi maknanya sama seperti yang terdapat di dalam Pasal 1320 KUH Perdata.

Agama Hindu merupakan agama yang tertua di dunia yang memiliki pengaruh yang sangat besar bagi kehidupan masyarakat dunia. Agama Hindu juga dikenal dengan istilah "SANATANA DHARMA “ yang artinya kebenaran yang langgeng dan abadi. Adapun yang menjadi tujuan dari Agama Hindu yaitu :

1. Tujuan Agama Hindu ditinjau dari sudut tujuan hidup manusia yaitu Catur Purusartha (Empat tujuan hidup manusia) terdiri dari Dharma, Artha, Kama dan Moksha yang akan melahirkan aspek keamanan, kesejahteraan, kenbahagiaan lahir batin dan Dharma yang mengandung pengertian aspek keadilan dan kepatutan.

2. Tujuan Agama Hindu Ditijnjau dari Sudut Dharma yaitu untuk mencapai “ Mokshartam Jagadhita ya ca iti dharma" yang artinya bahwa Dharma bertujuan untuk mencapai mOksa dan kesejahteraan dunia. (I Wayan Surpha 2005:6-7)

Di dalam Kitab Manusmerti atau Manawa Dharmasastra Pasal 11.6 mengatur tentang Sumber Hukum Hindu yaitu : 
1.Sruti (Wahyu)

2. Smrti (kodifikasi tafsir dan penjabaran dari Sruti)

3. Sila (Tingkah laku orang-orang yang mendalami Weda dan orang-orang yang beradab)

4. Sadacara atau Acara (Adat-istiadat serta kebiasaan-kebiasaan setempat) Atmanastuti (Rasa kepuasan diri) (I Wayan Surpha 2005:33)

Sumber hukum hindu telah diatur pula di dalam Manawa Dharmasastra Pasal 11.10 yang berbunyi :

Srutistu wedo wijnevo dharma sastra to wai smrtih te sarvathawam mamsye

Sabhyam dharmahi nibandhau”.

Artinya:

"Yang dimaksud dengan Sruti, ialah Veda dan dengan Smrti itu Dharmasastra, keduanya tidak boleh diragukan karena keduanya adalah kitab suci yang menjadi sumber dari hukum (dharma)".

Selanjutnya penetapan WEDA sebagai sumber hukum hindu diatur di dalam Manawa Dharmasastra Pasal11.6 yang berbunyi :

Wedo khilo dharma mulam

Smrti sile ca tad wedaim

Acarasca iwa sadhanam, atmanastuti rewa ca

Artinya :

Seluruh Weda merupakan sumber utama dari hukum, selanjutnya barulah Smrti dan tingkah laku orang-orang budiman, kebiasaan-kebaisaan dan akhirnya atmanastuti (rasa kepuasan diri).

Mengenai legalitas perjanjian atau kontrak bisnis diatur di dalam Kitab Manusmerti atau Manawa Dharmasastra Atha Astamo'dhyayah (Buku Ke-Delapan) Buku VIII Pasal 163 yang berbunyi :

Matton mattarttadhyadhinair

balena sthavirena va, asam baddha krtas caiva

Vyavaharo na siddhati

Artinya :

Perjanjian yang diadakan oleh orang yang mabuk atau gila atau menenderita sakit jiwa (karena penyakit dan sebagainya) atau yang dibawah pengampunan,oleh anak kecil atau orang yang sudah tua atau oleh orang yang tak diberi wewenang adalah tidak sah.

Berdasarkan bunyi Manawa Dharmasastra Atha Astamo'dhyayah (Buku KeDelapan) Buku VIII Pasal 163 di atas lebih menacu kepada kewenangan hukum atau kecakapan hukum para pihak yang membuat perjanjian, hal ini tentunya memiliki kemiripan dengan ketentuan Pasal 1320 KUH Perdata. Artinya orang yang mabuk atau menderita sakit jiwa atau gila atau karena penyakit yang parah atau dibawah pengampunan/bersalah melakukan perbuatan melawan hukum, anak kecil atau dibawah umur, orang yang sudah renta atau pikun dan orang yang tidak 
diberikan kewenangan atau kuasa maka perjanjiannya menjadi tidak sah atau cacat hukum sehingga konsenwensinya tidak memenuhi syarat subjektif dan dapat dibatalkan. Selain itu juga di dalam Buku VIII Pasal 164 mempertegas kembali tentang kekuatan hukum perjanjian atau kontrak yang dibuat oleh para pihak yang berbunyi :

Satya na bhasa bhavati

Yadyapi syat prati sthita

Bahis ced bhas yate dharman

Niyata dvyavahakirat

Artinya :

Suatu perjanjian yang telah dibuat bertentangan dengan undang-undang dan kebiasaan yang telah diakui dari orang-orang yang baik tidak mempunyai kekuatan hukum walaupun pembuatannya terbukti adanya.

Pasal 164 Manawa Dharmasastra di atas menunjukkan bahwa jika perjanjian dibuat oleh para pihak dan diketahui perjanjian itu bertentangan dengan undangundang dan kebiasaan maka telah ditegaskan bahwa perjanjian itu tidak mempunyai kekuatan hukum atau tidak memenuhi syarat legalitas. Jika dihubungkan dengan hukum nasional (terutama Pasal 1320 KUH Perdata) maka syarat objektifnya tidak terpenuhi yaitu kasusa yang halal (objek perjanjian itu bertentangan dengan undang-undang dan kesusilaan). Hal ini berarti bahwa Manawa Dharmasastra sangat rinci menguraikan mengenai legalitas suatu kontrak atau perjanjian.

Dalam hal kebatalan dan pembatalan kontrak secara hukum nasional diatur di dalam Pasal 1446 KUH Perdata sampai dengan Pasal 1456 KUH Perdata, dalam hal ini ada tiga penyebab timbulnya pembatalan perikatan atau perjanjian yaitu :

1. Adanya perjanjian yang dibuat oleh orang-orang yang belum dewasa dan di bawah pengampuan.

2. Tidak mengindahkan bentuk perjanjian yang disyaratkan dalam UU

3. Adanya cacat kehendak.

Khusus untuk cacat kehendak (wilsgebreken) adalah kekurangan dalam orang atau orang-orang yang melakukan perbuatan yang menghalangi terjadinya penyesuaian kehendak dari para pihak dalam perjanjian atau kontrak. (Salim HS 2001: 198). Selanjutnya ada tiga macam cacat kehendak yaitu :

a. Kekhilafan (dwaling) yaitu suatu penggambaran yang keliru mengenai orangnya atau objek perjanjian yang dibuat oleh para pihak.

b. Paksaan (dwang) yaitu suatu ancaman yang dilakukan oleh seseorang kepada orang lain atau pihak ketiga, sehingga memberikan kesan dan dapat menimbulkan ketakutan pada orang yang berakal sehat bahwa dirinya, orang-orangnya atau kekayaannya terancam rugi besar dalam waktu dekat (Pasal 1324 KUH Perdata).

c. Penipuan (bedrog). Penipuan adalah dengan sengaja mengajukan gambaran atau fakta yang salah untuk memasuki suatu perjanjian (Salim HS 2001: 199)

Selain itu cacat kehendak menurut common law system dinekal dengan istilah Undue Enfluence (penyalahgunaan keadaan ) hal ini berarti bahwa adanya politik 
etatisme yaitu golongan ekonomi kuat menekan golongan ekonomi yang lemah. Sedangkan di dalam Manawa Dharmasastra Pasal 168 berbunyi :

Baladdattam balad bhuktam

Baladyaccapi lekhitam

Sarvan bala krtan artha

Nakrtan manur abravit

Artinya :

Apa yang diberikan dengan kekerasan, apa yang dinikmati dengan kekerasan, demikian pula apa yang dipaksakan untuk menuliskannya dengan kekerasan serta semua transaksi yang diselenggarakan dengan kekerasan telah dinyatakan oleh Manu tidak sah.

Di dalam Pasal 168 Manawa Dharmasastra di atas maknanya sama dengan apa yang telah disebutkan dalam KUH Perdata khususnya tentang cacat kehendak termasuk juga istilah penyalahgunaan keadaan sehingga menyebabkan kontrak tersebut tidak memenuhi syarat legalitas suatu kontrak sehingga menjadi tidak sah.

Saat ini negara-negara di dunia telah memasuki era perdagangan bebas maka kontrak bisnis tidak lagi dibuat dengan akta yang menghadirkan para pihak tetapi dapat dibuat dengan kontrak secara elektronik termasuk pinjaman secara online (Fintech), hal ini merupakan kemajuan yang sangat luar biasa dalam dunia bisnis saat ini. Tentu dalam menghadapi fenomena ini hukum harus meresponnya dengan cepat dan progresif kalau tidak akan ketinggalan. Selanjutnya menjadi pertanyaan adalah bagaimana keabsahan atau legalitas kontrak atau perjanjian yang dibuat di dalam elektronik tentu hal ini tetap mengacu kepada unsur legalitas kontrak di dalam Pasal 1320 KUH Perdata dan tidak terdapat cacat kehendak sebagaimana yang dimaksud di dalam 1446 KUH Perdata sampai dengan Pasal 1456 KUH Perdata atau dalam kata lain bahwa pihak dalam kontrak atau perjanjian tersebut adalah benar-benar pihak yang namanya tertuang dalam komparisi, bahwa ia tidak berada di bawah paksaan, tipuan atau kekhilafan, serta perjanjian tersebut telah sesuai dengan kehendak para pihak. Jika dikatkan dengan Manawa Dharmasastra maka syarat legalitasnya harus sesuai dengan Buku VIII terutama Pasal 163, Pasal 164 dan Pasal 168.

Legalitas kontrak bisnis adalah hal yang sangat penting untuk dipatuhi oleh para pihak yang membuatnya untuk menghindari tidak sahnya suatu kontrak sebagaimana yang telah diuraikan di atas. Jika dikaitkan dengan agama, bahwa Agama Hindu adalah agama yang selalu menjunjung tinggi arti kesucian baik pikiran, perkataan dan perbuatan sebagaimana yang diatur di dalam Tri Kaya Parisudha. Kesucian menurut pandangan Agama Hindu sangat terkait dengan moral dan etika, sebab dari moral akan mencerminkan etika atau perbuatan yang dilakukan. Sama seperti halnya jujur dan beritikad baik dalam membuat dan melaksanakan kontrak maka sama dengan menjaga kesucian diri sendiri. Prinisp Iktikad yang baik adalah mematuhi isi kotrak yang telah dibuat oleh para pihak. Iktikad baik dalam hukum kontrak Romawi mengacu kepada tiga bentuk perilaku para pihak dalam kontrak, yaitu: Pertama, para pihak harus memegang teguh janji atau perkataannya; Kedua, para pihak tidak boleh mengambil keuntungan dengan tindakan yang menyesatkan terhadap salah satu pihak; Ketiga, para pihak mematuhi kewajibannya dan berperilaku sebagai orang terhormat dan jujur, walaupun kewajiban tersebut tidak secara tegas diperjanjikan (Wiryono Prodjodikoro, 
2006:56). Prinsip Iktikad yang baik ini mengajarkan kepada seluruh masyarakat terutama pebinsis aagar bersikap jujur dan menjunjung tinggi kebenaran sehingga apa yang menjadi tujuan dibuatnya kontrak tersebut menjadi tercapai.

Mengenai kesucian dan kejujuran ini telah dijelaskan di dalam ajaran Dasa Dharma yaitu sepuluh macam perbuatan yang baik yang patut disadari dan dilaksanakan oleh Umat Hindu. Segenap Umat Hindu diharapkan dapat mengimplementasikan ajaran ini dalam rangka terciptanya masyarakat yang aman, tentram dan damai. Dasa Dharma ini terdiri dari :

1. Dhriti yaitu bekerja secara sungguh-sungguh

2. Ksama yaitu mudah memberi maaf

3. Dama yaitu dapat mengendalikan nafsu

4. Asteya atau Asteneya yaitu tidak mencuri

5. Sauca yaitubersih atau suci

6. Indryani-graha yaitu dapat mengendalikan keinginan

7. Dhira yaitu berani membela yang benar

8. Widya yaitu sanggup belajar dan mengajar

9. Satya yaitu menjunjung tinggi kebenaran, kesetiaan dan kejujuran

10. Akrodha yaitu tidak marah

Selain itu mengenai etika dan moral ini juga dijelaskan di dalam Di dalam Kitab Sārasamuścaya sloka 259 menjelaskan tentang ajaran Dasa Yama Brata yaitu 10 jenis pengekangan diri berdasarkan upaya individu untuk menjauhi larangan agama sebagai norma kehidupan yang terdiri 1) Anresangsya yaitu tidak egois, 2) Ksama yaitu suka mengampuni dan tahan uji menghadapi pasang surutnya kehidupan, 3) Satia ialah jujur dan setia atau tidak ingkar janji, 4) Ahimsa yaitu kasih kepada makhluk lain, tidak membunuh, dan menyiksa secara sewenangwenang, 5) Dama yaitu dapat menasehati diri sendiri, orang harus dapat mengendalikan diri menguasai indriyanya atau nafsunya, 6) Arjawa yaitu dapat mempertahankan kebenaran artinya berpegang teguh pada kebenaran, 7) Priti adalah cinta dan kasih kepada sesama makhluk hidup, 8) Prasada yaitu berfikir dan berhati suci tanpa pamrih, 9) Madurya yaitu ramah tamah dan sopan santun, dan 10) Mardawa yaitu rendah hati dan tidak sombong (Putra dkk, 2013:135). Hal ini berarti bahwa dalam membuat kontrak atau perjanjian harus menghindari larangan dalam Agama Hindu sebagaimana yang dimaksud di atas. Penulis yakin bahwa jika ajaran dalam Agama Hindu ini diterapkan dengan konsekuen dalam kehidupan sehari-hari terutama dalam pembuatan dan pelaksanaan kontrak maka akan tercipta kehidupan yang aman dan nyaman dan membawa kesejahteraan. 


\section{SIMPULAN DAN SARAN}

\section{Simpulan}

1. Legalitas kontrak bisnis menurut hukum nasional terdapat di dalam Pasal 1320 KUH Perdata yaitu tentang syarat sahnya suatu perjanjian, sedangkan legalitas kontrak dalam Kitab Manusmerti atau Manawa Dharmasastra diatur di dalam Pasal 163, Pasal 164, Pasal 168.

2. Agama Hindu sebagai kebenaran yang abadi (Sanatana Dharma) selalu mengajarkan dan menjunjung tinggi kesucian dalam praktik kehidupan seharihari yang harus dipatuhi oleh segenap Umat Hindu (Dasa Dharma dan Dasa Yama Brata) sekalipun itu dalam pembuatan dan pelaksanaan kontrak, hal ini maknanya sama dengan penerapan prinsip iktikad baik yang menjadi salah satu asas dalam hukum kontrak di Indonesia.

\section{Saran}

1. Umat Hindu dalam melakukan perbuatan hukum dalam bidang hukum kontrak atau perjanjian harus mematuhi hukum nasional dan hukum Agama Hindu.

2. Umat Hindu harus menjaga kesucian diri dengan menerapkan prinsip iktikad (jujur dan menjunjung tinggi kebenaran dan aturan moral yang baik ) terutama dalam pembuatan dan pelaksanaan kontrak agar terhindar dari perbuatan melanggar hukum dan dosa.

\section{DAFTAR PUSTAKA}

HS Salim, 2001.Pengantar Hukum Perdata Tertulis BW, Jakarta. Sinar Grafika.

-----------, 2010 Perkembangan Teori Dalam Ilmu Hukum, Jakarta PT RajaGrafindo Persada.

Hernoko Yudha Agus, 2010. Hukum Perjanjian Asas Proporsionalitas Dalam Kontrak Komersial, Jakarta. Kencana Prenada Media Group.

Pudja. G dan Tjokorda, Rai Sudharta.2004.Manava Dharmasastra (Manu Dharmasastra) atau Veda Smrti Compidium Hukum Hindu, Surabaya. Paramitha.

Putra, Ida Bagus Rai, dkk. 2013.Swastikarana, Pedoman Ajaran Hindu Dharma. Parisada Hindu Dharma Indonesia. Jakarta.

Prodjodikoro, 2006. Wiryono,Asas-Asas Hukum Perjanjian, Bandung,Sumur. Surpha I Wayan, 2005. Pengantar Hukum Hindu, Surabaya. Paramita. 